\title{
Wild flower blooms again after 30,000 years on ice
}

Fruits hoarded by ancient ground squirrels give new life to prehistoric plants.

\section{BY SHARON LEVY}

$\mathrm{D}$ uring the Ice Age, Earth's northern reaches were covered by chilly, arid grasslands roamed by mammoths, woolly rhinoceros and long-horned bison. That ecosystem, known by palaeontologists as the mammoth steppe, vanished about 13,000 years ago. It has no modern counterpart.

Yet one of its plants has reportedly been resurrected by a team of scientists who tapped a treasure trove of fruits and seeds, buried some 30,000 years ago by ground squirrels and preserved in the permafrost (S. Yashina et al. Proc. Natl Acad. Sci. USA http://dx.doi.org/10.1073/ pnas.1118386109; 2012). The plant would be by far the most ancient ever revived; the previous record holder was a date palm grown from seeds roughly 2,000 years old.

The squirrels' burrows, 70 in all, were found on the banks of the lower Kolyma River in northeastern Siberia, 20-40 metres below the current surface of the tundra and surrounded by the bones of mammoths and other creatures. Some burrows contained hundreds of thousands of fruits and seeds, wonderfully preserved by the cold, dry environment.

Researchers had previously attempted to grow plants from seeds found in these ancient burrows, including sedge, Arctic dock, alpine bearberry and the herbaceous plant Silene stenophylla. Those seeds did begin to germinate, but then faltered and died back.

Tantalized, David Gilichinsky of the Russian Academy of Sciences' Institute of Physicochemical and Biological Problems in Soil Science in Pushchino decided to try a different approach (sadly, Gilichinsky passed away last week). He and his colleagues took samples of placental tissue from S. stenophylla fruits. The plant placenta - an example of which is the white matter

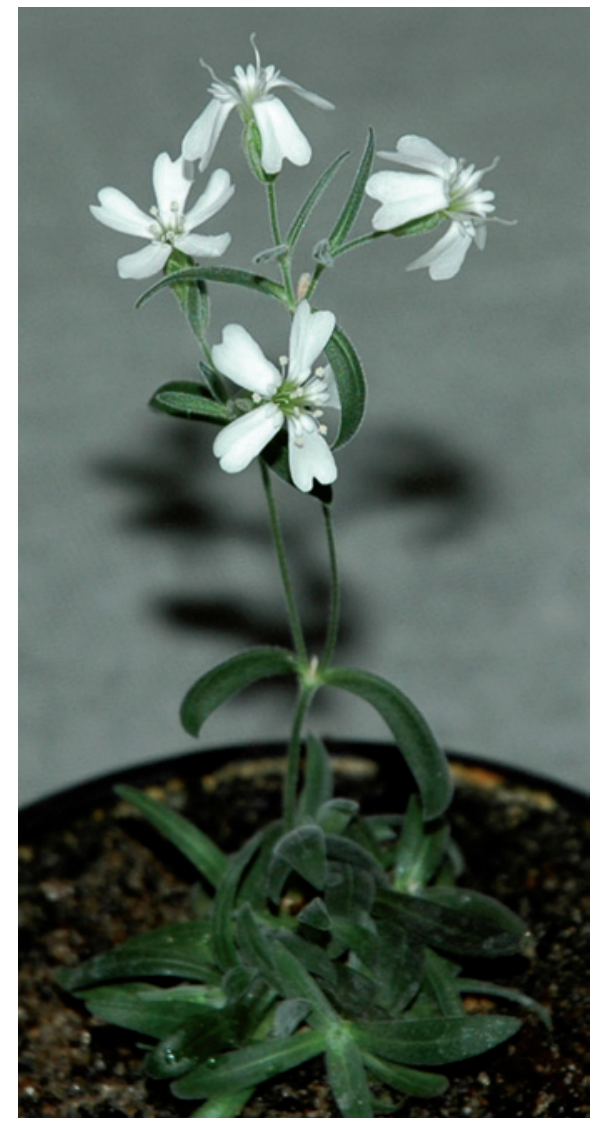

A prehistoric plant resurrected from frozen tissue.

inside a bell pepper — gives rise to and holds the seeds. The tissue produced shoots when it was cultivated in vitro, and the scientists used these to propagate more plants. They are the oldest living multicellular organisms on Earth, the team says.

The plants have already blossomed to produce fertile seeds, which were grown into a second generation of fertile plants. During propagation, the ancient form of the wild flower produced more buds but was slower to put out roots than modern S. stenophylla, which is found along the banks of the Kolyma. This suggests that the original has a distinct phenotype, adapted to the extreme environment of the Ice Age.

"I'm excited that someone has finally succeeded in doing this," says Grant Zazula of the Yukon Palaeontology Program in Whitehorse, Canada, who has investigated previous claims of ancient seed germination. "There is a good chance that extinct plant species could now be brought back to life from permafrostpreserved seeds."

Although some members of the mammoth steppe ecosystem survive, no place on Earth currently holds the same combination of grasses, sedge and wild flowers that have been found in the mummified guts of Ice Age mammoths or in the frozen hoards of squirrels (B. V. Gaglioti et al. Quatern. Res. 76, 373-382; 2011). Zazula speculates that living plant tissue from much earlier - hundreds of thousands of years ago - might also be revived, revealing evolutionary change over a longer timescale, and helping scientists to understand the lost ecology of periods such as the Ice Age.

\section{CLARIFICATION}

The table in the News story 'Obama shoots for science increase' (Nature 482, 283-285; 2012) was unclear about the make-up of the Food and Drug Administration's budget. Obama's request leaves the government's input nearly flat, but a rise in user fees from industry would lift the agency's overall 2013 budget to $\$ 4,486$ million.

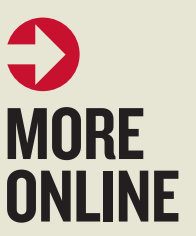

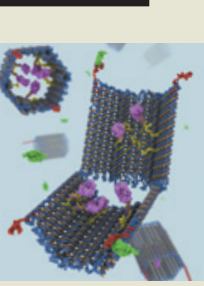

- DNA robot could kill cancer cells by seeking them out and delivering a deadly payload. go.nature.com/bzh4ya

\section{MORE NEWS}

- Tourette's-like disorder in New York school confounds experts. go.nature.com/ h6dmq1

- Citizen science goes extreme. go.nature.com/7ghzol

- Kilogram conundrum on the road to resolution go.nature.com/uldglw

\section{PODCAST}

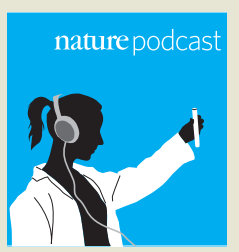

Alan Turing's birthday; the Y chromosome sticks around; and how cells sense pain. go.nature.com/qnk7uv 